\title{
National REDD+ policy networks: from cooperation to conflict
}

\author{
Maria Brockhaus $^{1}$ and Monica Di Gregorio ${ }^{2}$
}

\begin{abstract}
Reducing emissions from deforestation and forest degradation (REDD+) is a financial mechanism aimed at providing incentives to reduce carbon emissions from forests and enhance carbon stocks. In most forest-rich developing countries, policy actors, i.e., state and nonstate as well as international and national, are designing national REDD+ policies. Actors' interests and beliefs shape patterns of interactions, ranging from cooperation to conflict, and these interactions influence a country's direction and progress in REDD+ policy formulation and implementation. We used a comparative policy network approach to analyze the power structures in national REDD+ policy domains in seven countries. We drew on the typology of power structures defined by two dimensions, namely the distribution of power in the policy arena and the dominant type of interaction, cooperative or conflictual, among actors, and we mapped the progress of national REDD+ decision-making processes against these power structures. We tested three hypotheses and found that (1) national ownership over the policy process is a prerequisite for progress. In addition, (2) the level of concentration of power in an actor group can facilitate progress in REDD+; however, particularly when concentration of power is high, progress will be possible only if the interests of the most powerful are aligned with the objectives of REDD+ and address the drivers of deforestation and forest degradation. Furthermore, (3) although cooperation is perceived as ideal in any collective decision-making setting, a certain level of conflict is necessary for progress in REDD+ decision making. This applies particularly in more advanced national REDD+ domains, where, following a honeymoon phase during which most policy actors embrace the broad idea of REDD+, policy decisions must deal with difficult realities associated with negotiating established business-as-usual interests, which entails high political costs.
\end{abstract}

Key Words: comparative analysis; conflict; cooperation; policy networks; power; REDD+; social network analysis

\section{INTRODUCTION}

The idea of reducing carbon emissions through avoided deforestation, or RED, was first proposed in 2005, at the 11 th Conference of the Parties (COP 11) in Montreal. It soon evolved to include avoided forest degradation (REDD), and later, at COP 13 in Bali in 2007, the enhancement of carbon stocks, becoming REDD+, thus shifting from focusing exclusively on carbon emission reductions to having multiple objectives (Angelsen and McNeill 2012). From the outset, it was recognized that realizing REDD+ would require broad policy changes, such as changes in economic, regulatory, and governance frameworks including, for example, spatial planning, agribusiness, and extractive industry reforms, many of which are beyond the forestry sector (Kanninen et al. 2007). The countries that have entered into the REDD+ process are now at different stages, with some still undertaking policy design and technical readiness activities and others already implementing policies, often with the support of global initiatives such as the United Nations REDD (UN-REDD) Programme and the World Bank-led Forest Carbon Partnership Facility (FCPF) or through bilateral agreements. Overall progress has been much slower than expected (Angelsen et al. 2012), and, for the most part, national policy outcomes in terms of actual emission reductions or cobenefits are not yet observable. Consequently, most analysis of REDD+ achievements has been limited to improvements in technical capacity (Romijn et al. 2012) and the development of policies and measures (Wertz-Kanounnikoff and McNeill 2012).

The national policy arenas in which REDD+ is being debated involve a wide array of actors, i.e., national and international as well as state and nonstate, with varying levels of power, defined as the capacity to influence decision making on REDD+. Among these actors, networks are formed, and coalitions that collaborate or challenge each other emerge, all of which shapes national
REDD+ strategies to realize policy outcomes according to actors' interests and beliefs (Kenis and Schneider 1991).

We seek to determine how and to what degree policy actors' influence and interactions with each other are affecting progress in REDD+ policy making in the current international and domestic contexts. We undertake a comparative policy analysis, focusing on the analysis of policy networks, across seven countries: Brazil, Cameroon, Indonesia, Nepal, Papua New Guinea (PNG), Tanzania, and Vietnam. Following Kriesi et al. (2006), we investigate different types of power structures along two major dimensions: the distribution of power in the national REDD+ policy arena and the patterns of cooperative and conflictual interactions among actor groups. We use social network analysis to analyze and compare these power structures.

We begin with an overview of the international context and of the progress of REDD+ policy processes in each country. We follow this with a brief theoretical overview to provide a deeper understanding of the actors and their interactions in network structures, and we lay out the dimensions we use to identify typologies of power structures. We end by formulating three hypotheses on how power structures affect progress in policy making. After describing our methods, we present our results from the analysis of the typologies of power structures applied to the seven national REDD+ domains. We then discuss and refine the three hypotheses in view of our results and conclude with some remarks on the theoretical framework used to study political structures within specific policy domains.

\section{BACKGROUND}

REDD+ in the international context

REDD+ was included in the Bali Action Plan as a major outcome of COP 13 in 2007. However, a number of actors in the 
international arena raised concerns, primarily about offsetting, which was seen as a way for Annex 1 countries to avoid carbon emission reductions at home; governance implications, given the risk of recentralization of forest governance (Phelps et al. 2010); and negative social and livelihoods impacts, such as the risks associated with unclear tenure and the lack of recognition of indigenous peoples' rights (Griffiths 2009, Okerere and Dooley 2010, Larson et al. 2013).

Over time, REDD+, initially seen as a cheap and easy marketbased mechanism, became highly complex both because of the multiple objectives associated with it and because of the shift away from the original market-based idea with results-based payments toward financing through overseas development aid and attached conditionalities (Seymour and Angelsen 2012, Angelsen 2013).

Countries such as Norway, Australia, and the United Kingdom supported the initiative through bilateral agreements with Indonesia, Vietnam, and Brazil, among others. Multilateral initiatives to support strategy formulation and capacity building were established in 2008 through the FCPF and the UN-REDD Programme, which were joined by the Forest Investment Program (FIP) in 2009 (Westholm 2010). These actors influence national REDD+ policy agendas through funding and attached conditionalities, e.g., the Letter of Intent between Norway and Indonesia, and, together with international conservation NGOs, shape REDD+ pilot projects at the local level. Examples include the Nature Conservancy working in Brazil and Indonesia; the World Wildlife Fund (WWF) in Peru; the Kalimantan Forest Carbon Partnership in Indonesia, funded by the Australian Agency for International Development; and the Netherlands Development Organization (SNV) in Vietnam.

Besides uncertainties about REDD+ financing and the form, if any, that a global agreement will take, REDD+ is having to deal with national realities as political costs become more obvious (Peskett and Brockhaus 2009). As national governments are in the process of formulating forest mitigation policies, domestic power struggles are clearly emerging and are influencing REDD+ policies and progress.

\section{REDD+ in domestic contexts}

In the absence of quantitatively measurable outcomes such as emission reductions, Korhonen-Kurki et al. (2014:9, Table 2) define REDD+ progress as the establishment of "new institutions, procedures and capacity-building measures by committed actors," which are intended to support concrete policy formulations and outputs that build on a broad societal consensus for change. Indicators for progress include the completion of national REDD+ strategies and the establishment of effective coordination bodies and monitoring, reporting, and verification (MRV) systems. Policy change would include such economic, regulatory, and governance reforms as the devolution of rights to local users; the removal of perverse incentives, such as subsidies and concessions to economic interests driving deforestation and forest degradation; and policy reforms in the forestry industry that effectively reduce unsustainable extraction (Kanninen et al. 2007, Brockhaus and Angelsen 2012). The countries in our analysis started to engage with REDD+ at different times, and policy processes have advanced at different speeds (Fig. 1). Three phases are distinguished in national REDD+ policy processes: phase 1 refers to national policy formulation, the readiness phase; phase 2 refers to implementation; and phase 3 refers to resultbased payments (Meridian Institute 2009). Currently, among our case-study countries, only Brazil, Indonesia, and Vietnam have reached phase 2 (Korhonen-Kurki et al. 2014).

In the following paragraphs, we describe the progress each country has made with REDD+, looking at the level of engagement with international initiatives and the main national interests that affect the power structures in the REDD+ domain. These conditions have been identified as relevant based on a qualitative comparative analysis (QCA) on the same data set undertaken before this analysis (Sehring et al. 2013, Korhonen-Kurki et al. 2014).

Brazil is one of the countries where REDD+ has advanced the most, with policy reforms and demonstration sites in place and an established MRV system. Unlike the other countries we studied, it is not involved in the international initiatives of the UN-REDD Programme and the FCPF, although it has joined the FIP and has signed a bilateral agreement with Norway. Brazil, with its Amazonian states, took its own route after early domestic debates and an initial rejection of market-based carbon offsets. Having declared its commitment, the country has taken steps to reduce deforestation, despite controversy over the new forestry law, which opponents fear will reinforce the power of large-scale businesses, such as soybean farms and cattle ranching, that drive deforestation (Stickler et al. 2013). Land tenure issues are openly discussed, and equity considerations are prominent in REDD+ policy debates because of the presence of well-established environmental justice nongovernmental organizations (NGOs) concerned mainly with indigenous peoples' rights (May et al. 2011b, Di Gregorio et al. 2013, Gebara et al. 2014).

Indonesia also is advanced in terms of REDD+ policy progress. The president of Indonesia has driven the establishment of a REDD+ Task Force and implemented important policy changes, including the recently extended moratorium on new forest concession licenses. Unlike Brazil, Indonesia participates in all three major multilateral initiatives, UN-REDD, FCPF, and FIP, as well as bilateral partnerships with Norway, Australia, and the UK, among others, with a total of US\$4.35 billion committed over the next several years (FCPF 2013). Conflict between donors and national state actors emerged recently over the establishment of a new leading national institution for REDD+ because the REDD+ Task Force was set up as temporary, to be replaced with a permanent body. The disagreement concerns whether the Task Force's functions should be incorporated into the Ministry of Forestry or assigned to a new independent body (Ridwan 2013). Also trying to influence national REDD+ decision making are the large-scale businesses driving deforestation and forest degradation, such as those in the palm oil sector. Indonesia has a long and well-documented history of entrenched business and state interests, particularly in the forestry sector (Barr et al. 2010, Brockhaus et al. 2012, Indrarto et al. 2012, Luttrell et al. 2014). In addition, economic development is a high national priority, with related issues including demands by local governments to have the right to convert forest for development purposes and the launch of a new multibillion-dollar national development program known as MP3EI (Economic Masterplan 2011-2025), which overlaps with potential REDD+ areas (Indrarto et al. 2012, Gallemore et al. 2014, Moeliono et al. 2014). Civil society actors also are engaged in the REDD+ arena, where they are challenging 
Fig. 1. Key REDD+ policy events in seven countries.

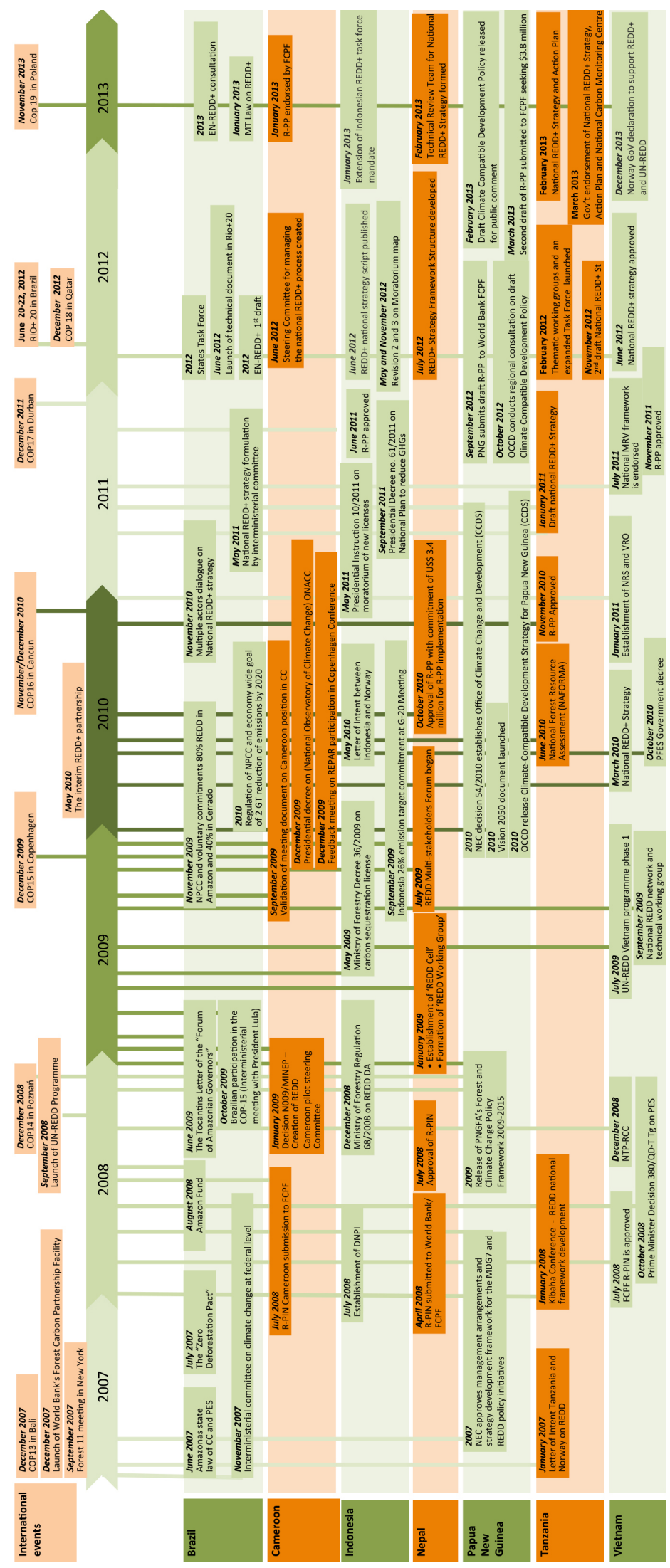


the state mainly on issues of environmental justice and equity, such as tenure and indigenous rights (Di Gregorio et al. 2013).

Vietnam has progressed steadily through the REDD+ readiness phase. It participates in the UN-REDD and FCPF initiatives. Overseas development agencies (e.g., SNV) provide additional financial and technical support for demonstration sites. Progress was supported by policy reforms on national payments for environmental services schemes and the prime minister's approval of the National REDD+ Program in June 2012. However, after early optimism and initially rapid policy progress, enthusiasm is waning. A growing concern is that government priorities, investments in infrastructure development such as hydropower plants, and the expansion of exports, including furniture, to China in particular will cause an increase in deforestation and forest degradation, not only within Vietnam but also through international leakage into neighboring countries such as Laos (Environmental Investigation Agency 2011, Pham et al. 2011). Another point of conflict is related to MRV: demands by REDD+ donors for transparency and independent verification are contentious for a government reluctant to provide access to data or to allow external verification processes because of national security concerns (Environmental Investigation Agency 2011). Vietnam is the only authoritarian regime among the seven countries studied; this political system affects the power structure in the national REDD+ domain, and domestic civil society has very limited access to national policy debates.

Tanzania has made slow progress in the REDD+ readiness phase, despite being the first of the seven countries to have signed a Letter of Intent on REDD with Norway, in 2007. It has adopted a participatory design for the policy process linked to its national REDD+ strategy, with the Secretariat of the REDD+ Task Force leading the process in consultation with subnational governments and civil society. In addition to support from UN-REDD and FCPF, Tanzania has received about US\$100 million since 2008 from Norway for its national REDD+ strategy development, REDD+ pilot projects, and capacity building, and the government of Finland is supporting the establishment of a monitoring system. Domestic civil society and local government actors, which participated in creating the national REDD+ framework, and international conservation NGOs are heavily involved in Tanzania's REDD+ process, which they are shaping through projects and involvement in the strategy development. However, this apparently broad participation is hardly reflected in drafts of the national strategy to date (Rantala and Di Gregorio 2014). Conflicts over whether the REDD+ financing architecture should be project based or managed through a centrally controlled national fund arise between central state actors and civil society, with project proponents largely promoting a subnational approach (Rantala and Di Gregorio 2014).

PNG was one of the countries that led the proposal to put RED on the United Nations Framework Convention on Climate Change (UNFCCC) agenda in 2005, and it participates in both the UNREDD and FCPF initiatives. However, progress in REDD+ policy formulation has been slow. The country has recently experienced political turmoil, with two men claiming to be the legitimate prime minister in 2011 (Guardian 2011). Corruption scandals involving so-called carbon cowboys, as were dubbed those who were more concerned with cashing in on carbon deals than with ensuring emission reductions, led to a crisis around the Office for Climate Change and the dismissal of the country's earlier lead international negotiator, Kevin Conrad (Lederer 2011). A revised version of its Readiness Preparation Proposal (R-PP) is currently under preparation. Some recent progress is indicated in new governance arrangements that include the establishment of the Office of Climate Change and Development and a draft of the Climate Change Authority Bill, whose ratification has been delayed. Among the seven countries, PNG has the strongest recognition of customary rights to land, as well as an explicit acknowledgment of the value of standing forest in its constitution (GovPNG 1975). Despite these, new land concessions to speed up economic development, known as special agriculture and business leases, are believed to threaten REDD+ goals and were challenged by a broad coalition of nonstate and state actors, which led to policy review and a moratorium on new licenses (Babon et al. 2014).

Nepal has a long history of community forestry but is also characterized by general political instability and has been in a political transition period since the elections in 2012. It has made some progress with REDD+. It submitted its R-PP to the FCPF in September 2010 and is developing its national REDD+ strategy. Both the FCPF and UN-REDD are involved in readiness activities in Nepal, and United States Agency for International Development is funding REDD+ demonstration sites. A national REDD+ cell, led by the Ministry of Forestry and Soil Conservation, is the coordinating agency. International conservation NGOs, including WWF, and international consultants support and shape the development of the national strategy, but civil society organizations have recently started to challenge the process on the grounds of a lack of meaningful consultation (Paudel et al. 2011). Although the long history of community forestry in Nepal has resulted in a wellorganized and quite influential federated structure of communitybased organizations, REDD+ is threatening to lead to the recentralization of the forestry sector (Bushley 2014).

Cameroon has made very little progress, despite its very early engagement with multilateral donors for REDD +. It only recently submitted its R-PP, which was finally endorsed by the FCPF in January 2013, with a budget of US\$28.9 million to draft the strategy and US\$60 million for demonstration activities. UN-REDD is also engaged in Cameroon. Otherwise, only a few key government actors are involved, i.e., the environment and forestry ministries, and some international conservation NGOs have realigned existing projects to fit REDD+ (Dkamela 2010, Kengoum 2011, Somorin et al. 2012). Past attempts to reform the forestry sector had significant shortcomings, partially because of lack of national ownership and strong resistance from those benefiting from the status quo of forest resource use and management (Dkamela et al. 2014). Next, we present the theoretical framework of the analysis, which results in six distinct power structures of national REDD+ policy domains.

\section{THEORETICAL FRAMEWORK}

Scholars of environmental governance in complex social-ecological systems emphasize the multidimensional character, i.e., multiactor, multiscale, and multilevel features, of these systems (Berkes and Folke 1998, Forsyth 2009, Ernstson et al. 2010, Poteete 2012). Political processes around climate change span across levels, from global to local, and involve policy networks formed by state and nonstate actors (Bodin and Prell 2011), where a policy network is understood as the structured pattern of interactions between policy 
actors in a policy domain (Marsh and Rhodes 1992). Climate change policy making takes place beyond formal state hierarchies, at national and subnational levels, through consultative processes involving NGOs and business actors, and at national and international levels, where actors engage in both bilateral and multilateral negotiations under the UNFCCC (Bulkeley and Newell 2010, Corbera and Schroeder 2011, Doherty and Schroeder 2011).

Policy network analysis provides a useful tool for examining the power structures in national REDD+ policy arenas (Newig et al. 2010), which are affected by both the international and the domestic contexts of REDD+. Different types and dimensions of power have been identified and analyzed in the literature on power (Arts 2004). We define power as the "capacity to achieve outcomes," where "the existence of power presumes structures of domination" (Giddens 1984:257). More specifically, in our case, we refer to the capacity to influence decision making on a particular policy problem (Biermann 2010). Both definitions focus of the ability of actors to achieve outcomes. Among the many other definitions is that of "having resources," where resources include, among others, reputation (Arts 2004), which includes the reputation of being a powerful actor. We use a measure of reputational power, or perceived influence, as a proxy for the capacity of policy actors to achieve desired policy outcomes (Heaney 2014, Fischer et al. 2009).

As described by Kriesi et al. (2006), configurations of power can be characterized along two dimensions: (1) the distribution of power in policy networks; and (2) the dominant type of interaction between actors and coalitions. Power can be concentrated or fragmented, and interactions can be predominantly cooperative or conflictual or present a balanced mix of cooperation and contention, which Kriesi et al. (2006) label "bargaining."

The first dimension, power, can be concentrated in one dominant actor or in a particular group of actors, or it may be distributed more evenly (Atkinson and Coleman 1989, Rhodes and Marsh 1992, Van Waarden 1992, as cited in Kriesi et al. 2006). Power may reside primarily in the national or international actors involved in the national policy process. The influence of international actors on national policy making has received special attention in the development aid literature, particularly in the analysis of structural adjustment programs and poverty reduction strategies (Brock et al. 2002, Driscoll et al. 2007). This body of literature suggests that lack of national ownership over policy making, which can be proxied by the concentration of power in international actors, partly explains policy failure. Luttrell (2007:2) notes that "for a system to be 'owned' nationally, it has to be driven by national objectives and motivations, and linked to existing programmes and policies." The development of national REDD+ strategies lies explicitly within the competence of national governments, yet there is evidence that international actors play a crucial role in shaping and contributing to national policy proposals, including through funding, thereby influencing national policy processes (Angelsen and McNeill 2012).

The second dimension is the dominant type of interaction in the policy network. Actors try to influence policy making in line with their interests, ideas, and beliefs (Sabatier and Jenkins-Smith
1993, Giddens 2009), and REDD+ policy making is no exception (Brockhaus and Angelsen 2012). Actors' behavior in a policy domain is influenced by their interactions with others: actors cooperate, bargain, or disagree with each other over specific policy issues. They use available resources to link and bond with each other to redefine or change situations (Latour 1986, Murdoch and Marsden 1995). As a consequence, groupings or coalitions around similar patterns of cooperation or conflict emerge. In the literature, cooperation is often attributed to the participation of nonstate actors in formal policy processes, which tend to accommodate state interests; whereas conflict is often associated with contention on the part of nonstate actors, such as social movements, working outside formal political processes (Katzenstein 1998). However, in policy processes, cooperation and conflict often coexist among state actors, among nonstate actors, between the two, and between coalitions. Increasingly observed in democratic polities, such situations have been labeled "conflictual cooperation" (Evers 1990) or "bargaining" (Kriesi et al. 2006).

Six distinct types of power structures emerge from this framework (Fig. 2). As seen in the figure, policy domains with a fragmented or diffused distribution of power can be characterized according to whether the dominant type of interaction is one of cooperation, bargaining, or conflict.

Fig. 2. Conceptual framework: typology of power structures (adapted from Kriesi et al. 2006).

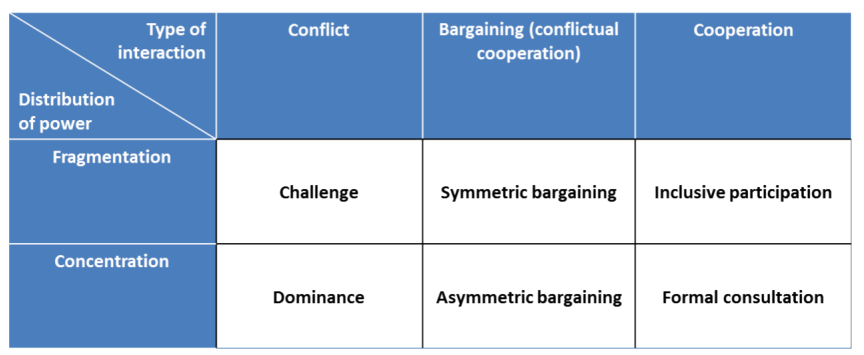

A situation of "challenge" is characterized by high fragmentation of power and the predominance of conflict or disagreement. Conversely, a situation of "dominance" emerges when power is concentrated and interactions are mainly conflictual; in such cases, the most powerful actors are able to impose their ideas and interests on others. A situation of "symmetric bargaining" emerges in domains with low concentration of power and a balance between cooperation and conflict. If power is concentrated and bargaining is the main type of interaction, "asymmetric bargaining" occurs. In this situation, actors challenging the status quo have minimal influence, and the extent of actors' participation in the REDD+ policy process is defined solely by the most powerful actors. Kriesi et al. (2006) suggest that when cooperation dominates interactions, the distribution of power becomes irrelevant. However, we argue that, in the REDD+ arena, cooperation within a highly concentrated power structure leads to a situation of "formal consultation." Conversely, "inclusive participation" emerges when power is more evenly distributed. We argue that the policy domain can move from one 
typology to another at different stages of the policy process, depending on contextual conditions such as the nature of the policy problem and the extent to which policy change is likely to affect existing interests.

Based on the previously discussed framework, the analysis that follows aims at opening the black box of policy processes to understand how policy change occurs (Grindle 1996). Kriesi et al. (2006) called for a comparative analysis that moves beyond generalized national-level conclusions about policy processes, to take international, country-specific, and policy-specific realities into account. We try to answer this call by analyzing how policydomain-specific political structures affect REDD+ policy developments. We derived our hypotheses from a combination of the theoretical reflections, the national REDD+ policy events in the case-study countries, the domestic and international contexts in which REDD+ is emerging and evolving, and a review of results of a QCA based on the same data set (Korhonen-Kurki et al. 2014).

We argue that in conditions of a high concentration of power, policy progress requires the most powerful actors to be aligned with proposed changes. This is because in a highly concentrated political system it is very difficult for more marginalized actors to influence policy processes. In addition, arenas that are characterized by complex social-ecological relations and high trade-offs between development and conservation agendas, as seen with REDD+, entail high political costs (Bumpus and Liverman 2011). We argue that, in such circumstances, a mix of conflict and cooperation can be more conducive to reformist agendas that lead to policy change as opposed to a situation of full cooperation, especially when reformist forces are not among the dominant actors. Finally, we suggest that for policy processes that lack strong buy-in from national governments, e.g., they are predominantly driven by international actors, policy progress is unlikely.

Using data from seven REDD+ countries, more specifically we test the following hypotheses:

1. A moderate to high concentration of power can provide opportunities to realize the broad policy changes required for REDD+, if the interests and policy proposals of the most powerful actors match the objectives of REDD+ and are compatible with the required policy changes.

2. A mix of conflict and cooperation can provide opportunities to realize the REDD+ agenda, if it occurs between reformists and status quo interests.

3. National ownership and the active involvement of powerful state actors are prerequisites for advancing REDD+ design and implementation.

\section{METHODS}

We selected REDD+ countries based on a number of criteria, including (1) representation of first-generation REDD+ countries that are participants in multi- and/or bilateral initiatives; (2) representation of global coverage and spatial distribution, i.e., Latin America, Africa, Asia, and Oceania; (3) presence of established REDD+ project initiatives; and (4) as an operational criteria, the presence of established partnerships to conduct the research. The first step in the policy network analysis was to identify the policy actors that are part of the national REDD+ policy domain. Identification of domain actors was based on a politico-economic analysis, a media analysis, and validation by an expert panel in each country (Brockhaus and Di Gregorio 2012). For each country, a roster of all relevant organizational actors was drawn up, and these organizations were contacted to take part in a survey. The roster was then used to elicit respondents' perceptions of the influence of other policy actors and the collaborative and conflictual interactions among them. The response rate to the survey varied from $56 \%$ to $100 \%$ (see Appendix 1).

We used Kriesi et al.'s (2006) procedure to investigate the two dimensions of power structures in the policy domain, namely the distribution of power and the dominant type of interactions. Concentration of power of a policy domain is determined by a reputational power measure (Knoke et al. 1996, Kriesi and Jegen 2001). Policy actors were first asked to identify from the full roster of policy domain actors those that they perceived as being "especially influential" in the REDD+ policy domain. The number of nominations each policy actor received is used as the reputational power indicator: the measure is called "in-degree centrality" in social network analysis (Scott 2000:69). To assess the concentration of power throughout the whole domain, we used two network-level measures. The first, network centralization, measures the centrality of the most central policy actor in the policy network in relation to how central all the other actors are (Wasserman and Faust 1994). The indicator is normalized over the theoretically largest sum of differences in any network with the same number of actors (Freeman 1978-1979). The indicator takes a maximum value of 1 when a single central actor is nominated as influential by all other actors in the domain and no others are nominated, i.e., maximum possible concentration of power, and a minimum value of 0 when all actors have the same numbers of nominations, i.e., equal power distribution. We express the indicator in percentages. The second measure is the coefficient of variation (CoV) of in-degree centrality, which also ranges from 0 to 1 and is an indicator of the overall spread of the distribution of reputational power, expressed in percentages. The higher the $\mathrm{CoV}$, the more unequal and hence more concentrated the distribution of power.

The second dimension is derived from the responses to two relational questions, one on collaboration, which is an indicator for cooperation among policy actors, and one on disagreement, which is an indicator of conflict (Kriesi et al. 2006). Respondents were asked to indicate all organizations on the roster to which the following applied:

- Question 1: With which other organizations does your organization collaborate on a regular basis on REDD+related issues?

- Question 2: With which organizations does your organization often find itself disagreeing on REDD+ policy issues?

The responses to these questions provided the data to build a multirelational network that includes both collaborative and conflictual relations. To identify the dominant type of interaction, we used a block-modeling procedure. Block modeling divides policy actors into blocks, i.e., subgroups in a network based on 
structural equivalence. Two actors, or nodes, are exactly structurally equivalent if they have the same relationships to all other nodes. Because exact structural equivalence is very rare, the procedure uses the degree of structural equivalence to assign actors into blocks (Wasserman and Faust 1994). We used the procedure called convergence of iterated correlations (Breiger et al. 1975) in UCINET, which allows the use of multirelational data, and we assigned blocks according to the best fit (Borgatti et al. 2002). We do not suggest that these blocks are necessarily policy coalitions, but we note that actors in the same blocks tend to exhibit similar cooperative and conflictual ties toward other actors in the policy domain (cf. Kriesi et al. 2006). To facilitate comparability, we restricted the number of blocks for each country to four, and to assess the dominant type of interactions, we investigated the patterns of ties across these four blocks. As an indicator of the power of a block, we used the average of the normalized reputational power indicator of the three most powerful actors in the block. In cases where the blocks vary substantially in size, this measure reflects the overall power of blocks better than the average of all actors in the block does, because this latter measure is very sensitive to block size and thus underestimates the power of large blocks with a small number of very influential actors and a large number of not very powerful actors (cf. Kriesi et al. 2006). We therefore assume that the overall power of a block is primarily determined by its most powerful actors.

A concern with reliability of the data relates to the relatively low response rates from Indonesia (56\%), Nepal (64\%), Cameroon $(66 \%)$, and PNG (68\%), and, in particular, the low participation of the most powerful actors in the survey (Kriesi et al. 2006). We therefore compared the reputational power of surveyed and nonsurveyed actors (Appendix 1). For all countries, actors that had been interviewed had higher average reputational power. However, the fourth most influential actor in PNG and the sixth most influential actor in Nepal did not participate in the survey, which could have affected the results slightly. The major concern is for Cameroon, where the most influential actor, i.e., the Ministry of the Environment, did not participate in the survey, which certainly affected the results. We present the results for all countries, although we recognize that the network measures for Cameroon remain incomplete because of the absence of the most central actor among the respondents.

When comparing collaborative and conflictual ties to assess the dominant type of interaction, we also have to take into account the tendency to underreport negative ties, i.e., conflict (White 1961, Labianca and Brass 2006). We account for this when interpreting the results.

Finally, the survey was administered in a different period in each country, although all were conducted between 2010 and 2012, and network data provide information only about the specific time when the survey was done. Whereas social network analysts tend to consider interactions among actors as largely stable over time (Scott 2000), the REDD+ policy domain is a relatively new domain and is particularly dynamic (Angelsen and McNeill 2012). We therefore interpret the results as referring to the particular national REDD+ policy context at the time of the survey.

\section{RESULTS}

National ownership of the REDD+ policy process

The role of international actors is an important aspect of the power structure of national REDD+ policy domains. Figure 3 depicts the ratios of the number of international to national actors in the policy domain as well as the ratio of the reputational power indicator, i.e., average normalized in-degrees, of these two groups. In all countries except PNG, the influence of international actors is disproportionately high compared with their numbers in the policy domain. In PNG, although around half of the actors are international, as a group they are less influential than domestic actors. In Nepal, PNG, and Brazil, the reputational power ratio is substantially lower than 1, and Brazil also has the lowest relative presence of international actors in the policy domain. Tanzania, Indonesia, and Vietnam have roughly a 1:1 ratio for reputational power of international versus national actors, indicating that international and national policy actors are perceived as having similar influence on the policy domain. Cameroon is an outlier, with a very strong presence of international actors, which are perceived as exerting much more influence on the policy domain than domestic actors. This clearly indicates that REDD+ policy formulation in Cameroon is being driven predominantly by international actors (Dkamela 2010, Di Gregorio et al. 2012).

Fig. 3. Relative presence and power of international and domestic policy actors.

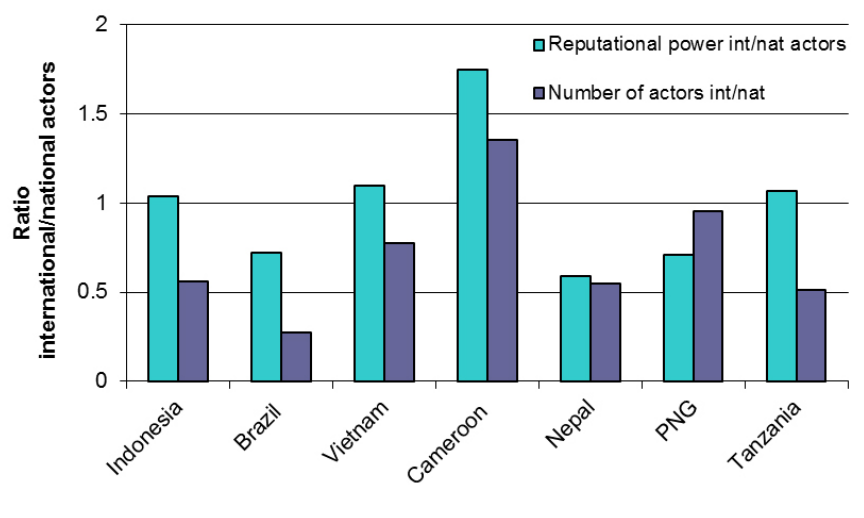

Distribution of power within the REDD+ policy domain

The level of concentration of power within the national REDD+ policy domain is assessed by two measures: network centralization, which indicates the extent to which power is concentrated in a single central actor, and the $\mathrm{CoV}$ of reputational power, which assesses overall distribution of power within the policy domain. For both measures, we observe the highest concentration of power in Indonesia, followed by Vietnam (Table 1). These two national policy domains display similar characteristics, with a single central agency, in Indonesia the Ministry of Forestry and in Vietnam the Ministry of Agriculture and Rural Development, commanding very high reputational power compared with other actors, i.e., high network centralization, and a highly unequal overall distribution of power in the REDD+ policy domain, i.e., high CoV. Following these are Nepal and Tanzania, where the most central actor, i.e., the REDD Forestry and Climate Change Cell and the Forestry and Beekeeping Division, respectively, is only slightly more influential 
Table 1. Concentration of power in national REDD+ policy domains.

\begin{tabular}{|c|c|c|c|c|c|c|c|}
\hline & Indonesia & Vietnam & Nepal & Tanzania & $\begin{array}{c}\text { Papua } \\
\text { New } \\
\text { Guinea }\end{array}$ & Brazil & Cameroon \\
\hline Network centralization $(\%)$ & 77 & 74 & 60 & 57 & 54 & 44 & 43 \\
\hline $\mathrm{CoV}$ of reputational power $(\%)^{\dagger}$ & 94 & 81 & 61 & 51 & 58 & 58 & 55 \\
\hline No. of policy actors & 64 & 52 & 34 & 53 & 45 & 56 & 42 \\
\hline
\end{tabular}

than the second most influential actor, i.e., the Department of Forest in Nepal and the Division of Environment, under the Vice President's Office, in Tanzania. However, Nepal is the only one of these four countries where two of the five most influential policy actors are domestic NGOs, i.e., the Nepal Federation of Indigenous Nationalities and the Federation of Community Forest Users in Nepal, indicating that despite a moderate concentration of power in Nepal, power is shared between state and domestic nonstate actors. Tanzania has another unique characteristic: although it has a fair concentration of power in the most central actor, it also has the lowest level of inequality in the overall distribution of reputational power.

PNG follows with a slightly lower, i.e., moderate, concentration of power in the most influential actor, the Office of Climate Change and Development, with two other actors being quite close in terms of influence, one of which is a nonstate actor, the Papua New Guinea EcoForestry Forum. Nevertheless, the overall distribution of power is slightly more unequal than in Tanzania. Brazil and Cameroon display signs of fragmentation of the policy domain, given the much lower concentration of power in the most central actor. Brazil is the only country we studied where the actor with the highest reputational power, the Amazon Environmental Research Institute, is not only a nonstate agency but also a regional actor. This testifies to a relatively low dominance of federal state actors in the policy domain and to the fact that both nonstate and state actors from the Amazonian states are most proactively driving national policy decisions on REDD+ (May et al. 2011a). A low level of concentration of power could be desirable in a policy domain to avoid dominance by a single key actor, but when coupled with the strong influence of international actors, it might be a sign that national actors are weak, as seems to be the case in Cameroon. However, although Brazil and Cameroon have similarly low levels of concentration of power, the causes are completely different. In the case of Cameroon, the low concentration of power is because of the absence of very influential central state actors: only one of the five most influential actors interviewed is a state actor, i.e., the forestry ministry, and the other four are either intergovernmental organizations or international NGOs. This predominance of international actors raises doubts, as mentioned earlier, about national ownership of the REDD+ domain in Cameroon. In addition, Cameroon has lower overall inequality in the distribution of reputational power than Brazil, indicating that power is more fragmented in the REDD+ domain in Cameroon than in Brazil.

\section{Cooperation versus conflict}

To assess the dominant type of interactions, following Kriesi et al. (2006), we compared the density ratio of cooperative to conflictual ties in the seven national REDD+ domains across four blocks of actor groups (Figs. 4 and 5). In theory, a density ratio of conflictual to cooperative ties across blocks of 1 would indicate a perfect balance between these two relations. However, given the substantial evidence that respondents tend to be much more reluctant to report negative, e.g., conflict, than positive relations, we consider ratios less than 0.5 to indicate dominance of cooperation; ratios between 0.5 and 0.8 as situations of bargaining, i.e., a mix of cooperation and conflict; and ratios greater than 0.8 as situations where conflict is dominant (White 1961).

Each block contains a group of actors that have similar ties to other policy actors in the domain. We labeled each block in each country according to the most dominant types of actors. In Figures 4 and 5 , the size of a block indicates the reputational power index of the block, and the ties between blocks are labeled according to the dominant type of tie, i.e., cooperation, bargaining, or conflict, and the value of the tie, i.e., number of ties connecting two blocks. The bigger the node, the more powerful that group of actors is. Solid arrows indicate the dominance of collaborative ties, arrows with vertical lines represent conflictual ties, and dashed ties represent bargaining across blocks. The width of the ties reflects the total number of ties across blocks.

In Brazil, conflict is most apparent in all blocks, followed by cooperation and bargaining. Most powerful are federal state actors, some of which are allied with private business interests (block 1), yet the block dominated by domestic NGOs primarily based in the Amazonian states is almost as influential (block 2). The dominant relations between these two blocks are of conflict and bargaining. In addition, the interaction between federal government agencies (block 1) and state-level government actors is predominantly conflictual (block 3 ), which reveals the tensions between federal government and state-level government actors and NGOs (May et al. 2011a). Most cooperative ties occur between the mixed group (block 4) and the domestic NGO group (block 2). Unlike federal government actors, state-level government actors from the Amazon (block 3) tend to collaborate with domestic NGOs (block 2) and the mixed group (block 4).

In Indonesia, there is a clear split among central state actors. The alliance of the Ministry of Forestry, provincial state actors, and key business actors (block 1) is much more powerful than any of the other three blocks. Block 3 is much less influential despite including the REDD+ Task Force and business actors. Disagreement among the key state actors in these two blocks is evident, indicating that a power struggle is occurring within the state. Otherwise, conflict is reported mainly by domestic 
Fig. 4. Patterns of interactions in national REDD+ policy domains.
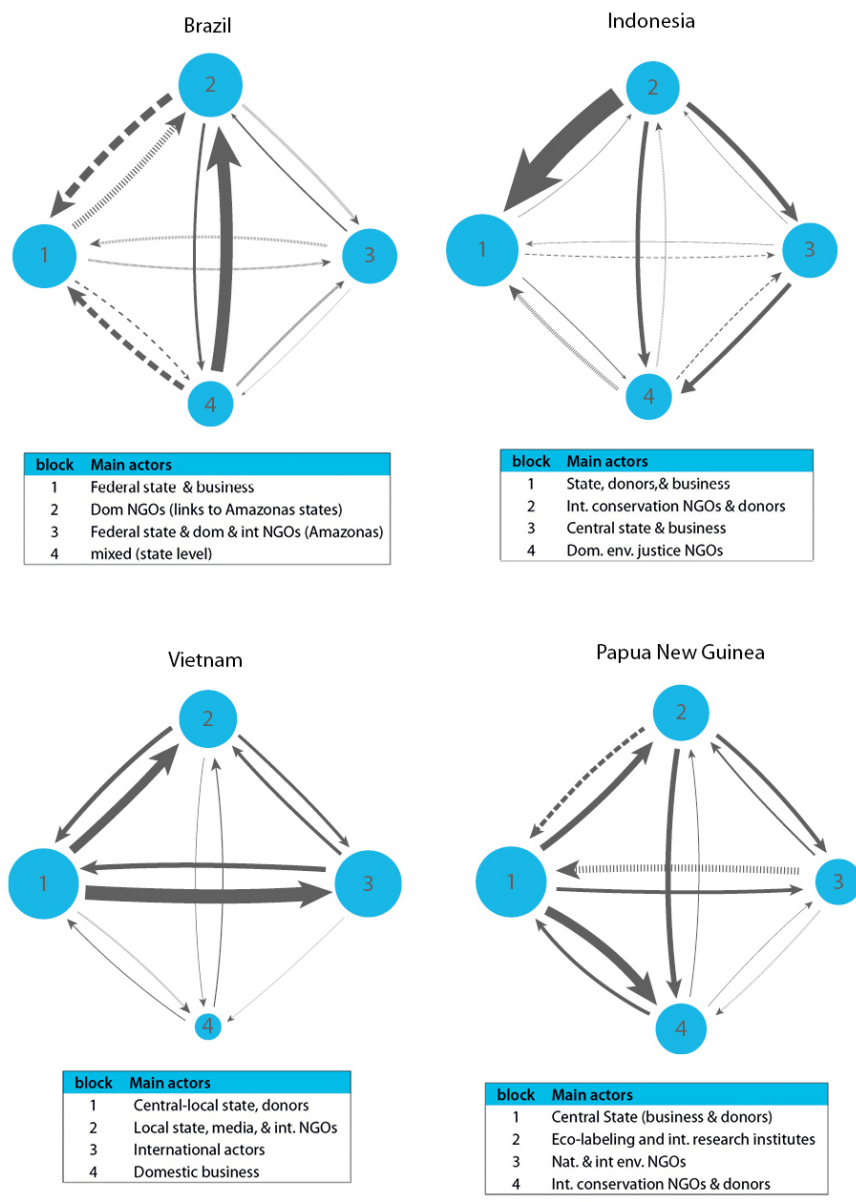

Legend:
in-degrees (reputation power)

environmental justice NGOs (block 4) and, to a lesser extent, by international NGOs (block 3). Environmental justice NGOs (block 4) have little power in the domain. Central state actors (block 1) mainly disagree and have conflictual or bargaining relations with all other blocks, whereas international NGOs and donors (block 2) tend to collaborate with the other three blocks. Overall, although cooperation has the largest number of ties, cooperation and conflict are similarly dominant across blocks, indicating an overall situation of conflictual cooperation in Indonesia's REDD+ domain.

In Vietnam, cooperation dominates interactions across all blocks. The two dominant blocks are formed by central and local state actors and donors (block 1) and intergovernmental organizations, donors, and international research institutes (block 3). Block 1 reports most collaborative ties predominantly with block 3 , but also with block 2, which includes local state actors, the media, and some international NGOs. The only conflictual relations are reported by
Fig. 5. Patterns of interactions in national REDD + policy domains.
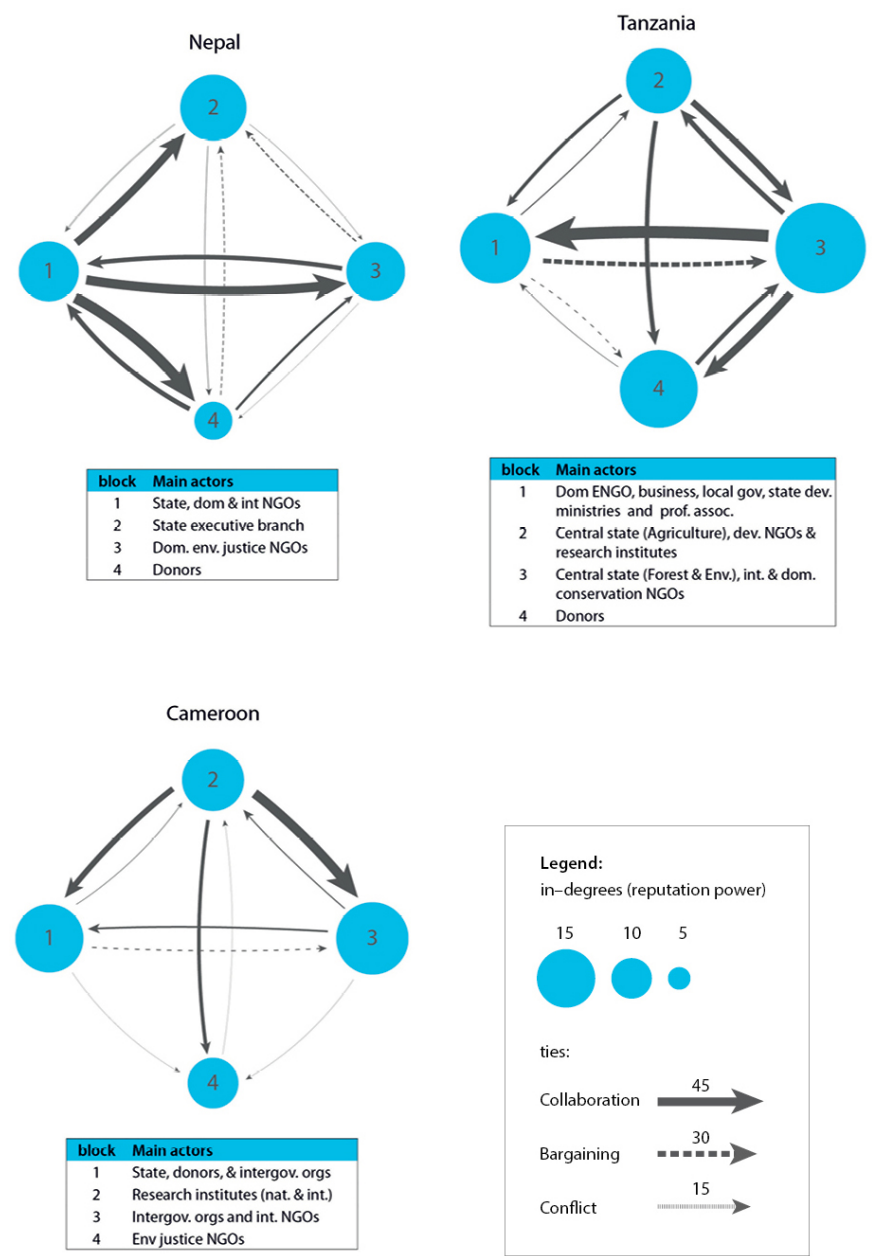

the dominant state actor (block 1) toward domestic businesses (block 4). This conflict is related to benefit-sharing arrangements for payments for forest-related environmental services and the resistance of the business sector to accept responsibility for these payments, as required by law (Pham 2011). Interestingly, however, all but one business actor (block 4 ) report cooperative ties with state actors. This seems to indicate reluctance to openly admit disagreement on the part of business actors in Vietnam, because responses to the semistructured interviews reveal tensions on both sides (Pham et al. 2014). This reluctance to express disagreement might not be confined to domestic business actors, given that international actors exclusively report cooperative ties.

In PNG, the mix of cooperative and conflictual ties is more evident, with most disagreement again directed toward the most powerful block (1), which includes central state actors and business representatives, e.g., Oil Palm Research Association. It is predominantly national and international NGOs (block 3) that express disagreement, whereas the block dominated by international research institutes (block 2) has a predominantly bargaining relation with block 1 . However, overall there is 
substantial cooperation in the policy domain, with the most powerful state-dominated block (1) and the block representing international NGOs and Washington-based donors (block 4) reporting dominance of cooperation with all other blocks.

In Nepal, where very few bargaining or conflictual relations are reported, the arena is clearly dominated by cooperation. The most influential block is formed by state actors from the executive branch working on forest and the environment (block 2). Block 1 is the second most influential block and includes state actors working on climate change and agriculture; the Federation of Community Forest Users of Nepal, which is the most powerful domestic civil society federation; and international NGOs. Most cooperative ties are reported by actors in block 1, with the highest number of cooperative ties going to donors (block 4). Interestingly, the block dominated by state actors working on climate change and agriculture (block 1) acknowledges substantial cooperation with the NGO-dominated block (3), which is uncommon in other countries. This is likely because of the presence of the most important civil society organization, i.e., Federation of Community Forest Users of Nepal, in block 1, which has strong ties to domestic NGOs. There are only two dominant bargaining relations (from block 3 and 4), both of which are directed toward the most powerful block (2), which indicates that conflictual cooperation dominates relations between the state and donors (block 3 ).

In Tanzania, cooperative relations are clearly dominant. The most powerful block (3) is formed by central state actors active in forestry and environment and international and domestic conservation NGOs. Most collaborative ties across blocks emanate from this block and link to other domestic environmental NGOs, local government, and other state actors working primarily on agricultural issues (block 2) and to donors (block 4). The fact that block 4 is the second most influential reveals the relatively strong influence of donors, and international actors in general, in Tanzania's REDD+ policy domain. The only relations that are dominated by bargaining emanate from a mixed block featuring, in particular, domestic environmental NGOs (block 1), which reveals a situation of conflictual cooperation with the two dominant blocks (3 and 4).

Finally, Cameroon features the lowest density of interactions across blocks of any country we studied, indicating that although collaboration is dominant, it is somewhat limited in scope. It is also the only country where the most powerful block is formed almost exclusively by intergovernmental and international organizations and does not include any key state actors, apart from peripheral state agencies linked to economic development. Of greatest concern is that this block shows little sustained interaction with the other blocks. Most key state actors are in block 1, which is less influential and even less engaged in collaboration with others, including international organizations. Most cooperative ties emanate from the third most influential block (2) and are directed toward the two most powerful blocks ( 3 and 1 ). Block 2 is dominated by international research institutes that are very much engaged in informing policy in Cameroon and clearly reach out to both intergovernmental and national state actors in the policy domain. Key state actors seem quite isolated, and it is international research institutes that act as brokers between the two dominant blocks, linking state and donor organizations in collaborative relations.

\section{DISCUSSION}

\section{Concentration of power for a reformist REDD+ agenda}

Among the three countries that have made the most progress with REDD + , the policy domains in Indonesia and Vietnam display a substantial concentration of power, whereas the arena in Brazil is one of the least polarized of all the countries we studied. We argue that in domains where power is highly concentrated, the agenda of the most powerful actors/coalitions, i.e., their beliefs, interests, and policy proposals, matters a great deal. To move forward with an effective REDD+, the leadership in the policy domains in Indonesia and Vietnam will require a reformist agenda. This seems to be partly the case in Vietnam, where the REDD Office of the Ministry of Agriculture and Rural Development has strong control of the national REDD+ agenda, with the support of international actors such as UN-REDD and the United Nations Development Programme. The policy formulation process entails larger reforms, although a major risk that characterizes REDD+ domains where power is highly concentrated among key state actors is the exclusion of the claims and demands of other stakeholders, particularly domestic civil society; this clearly seems to be the case in Vietnam (Pham et al. 2011) and, to a lesser extent, in Indonesia (Indrarto et al. 2012). Given this exclusion, policy implementation is unlikely to satisfy civil society's demands, which are largely concerned with the distribution of benefits and safeguards (Di Gregorio et al. 2013).

In Indonesia, power is concentrated in two actors with rather contradicting agendas: the most powerful actor by far is the Ministry of Forestry, which has strong ties to the lobby of largescale businesses that has supported forest exploitation for decades (Barr 2001, Moeliono et al. 2013). However, the second most powerful actor is the REDD+ Task Force, which is supported by the Indonesian presidency and frequently challenges business as usual. The tensions between these two agencies became visible in the controversy over the moratorium on new forest concessions, which, although now in force, has been described as inadequate in scope and duration (Murdiyarso et al. 2011). However, the fact that there is a powerful reformist counterbalance to business-asusual interests could explain in part the progress made on REDD+.

That Brazil has made progress with REDD+ despite attempts to reform the forestry code in favor of, for example, large-scale ranching interests suggests that, in the presence of high fragmentation of power, numerous policy actors challenging the status quo have been able to wield some influence over the policy process. However, fragmentation of power provides opportunities to reform policies in support of REDD+ objectives only if it signals an inclusive and open policy process, as opposed to a fully fragmented arena that lacks leadership and interest in larger changes in the forestry sector, as seems to be the case in Cameroon (Dkamela et al. 2014).

\section{Bargaining for change}

Hypothesis 2, which suggests that a mix of conflict and cooperation facilitates change and progress holds with respect to the countries where REDD+ has advanced the most. In Brazil, we observe the dominance of conflict and in Indonesia of conflictual cooperation. However, the dominant pattern of interactions is strongly related to the country's stage in the design of REDD+. Countries in the early stages of national REDD+ 
policy debates, such as Nepal, tend to be in a "honeymoon" phase where cooperation is dominant. However, as seen in Brazil and Indonesia, power struggles intensify and bargaining and conflict become dominant when the national REDD+ policy process starts to address specific policies and measures, particularly on controversial issues such as benefit sharing (Luttrell et al. 2013, Pham et al. 2013).

In all countries where bargaining and conflict are reported, i.e., all except Vietnam, the actor groups subject to the most challenges are state actors and business interests associated with deforestation and forest degradation. Those making the challenges are predominantly civil society actors. Thus, it would seem that, at least in democratic polities, opportunities for a reformist REDD+ agenda to progress likely arise through the presence of bargaining and conflictual relations between reformist nonstate actors and business-as-usual interests. This is not to say that state actors cannot support a reformist agenda; indeed many individual state agencies do, but our evidence suggests that reformist actors tend to be less powerful than those state actors whose interests are linked to the main drivers of deforestation.

As seen, cooperation is the predominant pattern of interaction in Vietnam, Tanzania, and Cameroon. However, we argue that contestation in Vietnam is underreported and latent, i.e., not openly expressed (Pham et al. 2011), and hence that the dominance of cooperation reflects not a situation of mutual agreement but rather the lack of openness of the country's political regime and the inability of nonstate actors, both national and international, to openly express dissent. Cooperation also dominates the interaction in Tanzania, and although one could interpret this as ideal, Tanzania seems to be trapped by the lack of a political opposition powerful enough to effectively challenge the policy actors driving deforestation and forest degradation, both within and outside the state. Tanzania has finalized its REDD+ strategy, but key decisions have not yet been made, for example on whether to adopt a centralized or nested institutional design for REDD+ and on the approach to the benefit-sharing mechanism. Because the network data provide a snapshot of each policy arena at the time of the survey, it will be very interesting to observe whether Tanzania and Nepal will enter a phase of conflict or bargaining in the future, or whether further progress can be made under a predominant pattern of cooperative interactions. Apart from Vietnam, where the dominance of cooperation reflects more the context of an authoritarian political regime than genuine agreement, dominance of cooperation has not yet resulted in rapid and substantial progress. In Cameroon, interest in REDD+ and related reforms in and beyond the forestry sector seems to be very low, despite the country's early participation in multilateral REDD+ initiatives (Kengoum 2011, Dkamela et al. 2014). Thus, in this case, lack of challenge and conflict seems to indicate that the national government is not fully engaged.

\section{National ownership as a prerequisite for progress}

The fact that the policy arena in Cameroon is characterized by both dominance of cooperation and fragmentation of power and yet the country has not made rapid progress with REDD+ points to the importance of national ownership, thus confirming our third hypothesis. Where state actors that have the authority to make REDD+ policy decisions show little leadership and the most influential actors are international actors, opportunities for substantive progress toward REDD+ objectives are limited, as seen in Cameroon. The lack of a binding international climate change agreement alone cannot be the main explanation, because this affects all countries investigated, some of which exhibit very strong ownership of the REDD+ process. One explanation that is supported by the literature is the lack of technical capacity and limited state resources (Brown et al. 2010). Our evidence confirms that an additional contributing factor is the failure by powerful government actors to commit to policy reforms addressing drivers of deforestation and forest degradation (Dkamela 2010, Somorin et al. 2012). The cases of the most successful (Brazil, Vietnam, and Indonesia) and least successful (Cameroon) countries clearly support the hypothesis that, in the absence of strong political commitment and leadership by national actors, little progress with REDD+ is likely to be made. Although countries with low technical capacity, such as Cameroon, do require substantial support from the international community, the weak engagement of key national actors might limit opportunities for progress with REDD+ and greatly impede implementation, primarily because of the "political inaction" of domestic state actors (Bell 1994 cited in Newell 2000:80). There are many possible explanations for political inaction. One contributing factor is the collusion between logging interests and government officials, which reveals a clear conflict of interest among some state actors (Alemagi and Kozak 2010), although such problems are found in other countries as well (Casson and Obidzinski 2002, World Bank 2006, Sikor and To 2011).

\section{CONCLUSION}

The power structures in a country affect its progress in national REDD+ policy making, yet the context and the stage of REDD+ shape these power structures in turn. Analyzing the distribution of power, the dominant patterns of interactions, and the specific interests of policy actors helps to understand how REDD+ is evolving.

As described previously, REDD+ progress is understood as a movement through three phases: a readiness phase, where the focus is on improving technical capacity and developing a national REDD+ strategy, followed by a phase of implementation of the policies and measures proposed in the national strategy, and a final phase in which performance-based payments are made (Meridian Institute 2009, Wertz-Kanounnikoff and McNeill 2012). We find that most REDD+ countries are getting "stuck" somewhere in phase 1 or in the early stages of phase 2 (KorhonenKurki et al. 2014), when political costs become apparent and power struggles emerge. Our findings show an initial "no-regrets stage," a honeymoon period characterized by cooperation. During this early stage in national REDD+ policy processes, countries seem to embrace REDD+ as a general idea, and segments of the international community provide the dowry in the form of finance and investments to strengthen technical capacity. However, in most REDD+ domains, there follows a "power struggle stage," during which conflict and contestation become dominant. When policy actors must decide on the concrete details of their national REDD+ strategies, in the absence of obvious short-term win-win outcomes, such struggles intensify. 
The slow progress in many national REDD+ domains has been met with greater efforts among the REDD+ community to develop performance measurements and indicators to assess policy progress. We conclude that, to understand the challenges and opportunities for REDD+ progress and to develop meaningful performance assessments, it is necessary to take into account how the power structures in REDD+ policy domains shift over time. This will require the unpacking of the political process occurring during each of the three phases of REDD+ in terms of a detailed analysis of which issues are on the policy agenda at specific times, and of the influence, interests, and relations of key policy actors.

Responses to this article can be read online at: http://www.ecologyandsociety.org/issues/responses. $\mathrm{php} / 6643$

\section{Acknowledgments:}

This research is part of the policy component of CIFOR's Global Comparative Study on REDD+ (http://www. forestsclimatechange. org/global-comparative-study-on-redd.html). The methods applied in this study build partially on research undertaken by the Comparing Climate Change Policy Networks program ( compon.org), funded by the National Science Foundation. The authors would like to express their deep gratitude to our partners and the individual country teams in the global comparative study, without whose work in the research countries this comparative paper would not have been possible. In particular, we would like to thank Andrea Babon, Bryan Bushley, Guy Patrice Dkamela, Caleb Gallemore, Maria Fernanda Gebara, Moira Moeliono, Thuy Thu Pham, and Salla Rantala. Many thanks also to Frances Seymour and all participants in the Module 1 policy network workshop in Barcelona 2013, who provided useful comments on an earlier version of this paper. Sofi Mardiah, Januarti Sinarra Tjajadi, Christine Wairata, Eko Prianto, Danil Rahadian, and Imogen BadgeryParker played highly valuable roles in research support and editing. Funding for CIFOR's research was provided by the Norwegian Agency for Development Cooperation, the Australian Agency for International Development, the UK Department for International Development, and the European Commission.

\section{LITERATURE CITED}

Alemagi, D., and R. A. Kozak. 2010. Illegal logging in Cameroon: causes and the path forward. Forest Policy and Economics 12 (8):554-561. http://dx.doi.org/10.1016/j.forpol.2010.07.008

Angelsen, A. 2013. REDD+ as performance-based aid: general lessons and bilateral agreements of Norway. World Institute for Development Economics Research (WIDER) Working Paper No. 2013/135. United Nations University-WIDER, Helsinki, Finland.

Angelsen, A., M. Brockhaus, W. D. Sunderlin, and L. V. Verchot. 2012. Introduction. Pages 1-12 in A. Angelsen, M. Brockhaus, W. D. Sunderlin, and L. V. Verchot, editors. Analysing REDD+: challenges and choices. Center for International Forestry Research, Bogor, Indonesia.
Angelsen, A., and D. McNeill. 2012. The evolution of REDD+ Pages 30-49 in A. Angelsen, M. Brockhaus, W. D. Sunderlin, and L. V. Verchot, editors. Analysing REDD+: challenges and choices. Center for International Forestry Research, Bogor, Indonesia.

Arts, B. 2004. Non-state actors in global governance: three faces of power. Max-Planck-Projektgruppe Recht der Gemeinschaftsgüter, Bonn, Germany.

Babon, A., D. McIntyre, G. Y. Gowae, C. Gallemore, R. Carmenta, M. Di Gregorio, and M. Brockhaus. 2014. Advocacy coalitions, REDD+, and forest governance in Papua New Guinea: how likely is transformational change? Ecology and Society 19(3): 16. http://dx.doi.org/10.5751/ES-06486-190316

Barr, C. 2001. Banking on sustainability: structural adjustment and forestry reform in post-Suharto Indonesia. Center for International Forestry Research, Bogor, Indonesia.

Barr, C., A. Dermawan, H. Purnomo, and H. Komarudin. 2010. Financial governance and Indonesia's Reforestation Fund during the Soeharto and post-Soeharto periods, 1989-2009: a political economic analysis of lessons for REDD+. Occasional Paper No. 52. Center for International Forestry Research, Bogor, Indonesia.

Berkes, F., and C. Folke, editors. 1998. Linking social and ecological systems. Cambridge University Press, Cambridge, UK.

Biermann, F. 2010. Beyond the intergovernmental regime: recent trends in global carbon governance. Current Opinion in Environmental Sustainability 2(4):284-288. http://dx.doi.org/10.1016/ j.cosust.2010.05.002

Bodin, Ö., and C. Prell. 2011. Social network analysis in natural resource governance: summary and outlook. Pages 347-373 in Ö. Bodin and C. Prell, editors. Social networks and natural resource management: uncovering the social fabric of environmental governance. Cambridge University Press, Cambridge, UK. http:// dx.doi.org/10.1017/CBO9780511894985.015

Borgatti, S. P., M. G. Everett, and L. C. Freeman. 2002. UCINET for Windows: software for social network analysis. Analytic Technologies, Harvard, Massachusetts, USA.

Breiger, R. L., S. A. Boorman, and P. Arabie. 1975. An algorithm for clustering relational data with applications to social network analysis and comparison with multidimensional scaling. Journal of Mathematical Psychology 12:328-383. http://dx.doi. org/10.1016/0022-2496(75)90028-0

Brock, K., R. McGee, and R. Ssewakiryanga. 2002. Poverty knowledge and policy processes: a case study of Ugandan national poverty reduction policy. Research report. Institute of Development Studies, Brighton, UK.

Brockhaus, M., and A. Angelsen. 2012. Seeing REDD+ through 4Is: a political economy framework. Pages 15-30 in A. Angelsen, M. Brockhaus, W. D. Sunderlin, and L. V. Verchot, editors. Analysing REDD+: challenges and choices. Center for International Forestry Research, Bogor, Indonesia.

Brockhaus, M., and M. Di Gregorio. 2012. A brief overview: component 1 on national REDD+ policies and processes. CIFOR Infobrief No. 13. Center for International Forestry Research, Bogor, Indonesia. 
Brockhaus, M., K. Obidzinski, A. Dermawan, Y. Laumonier, and C. Luttrell. 2012. An overview of forest and land allocation policies in Indonesia: is the current framework sufficient to meet the needs of REDD+? Forest Policy and Economics 18:30-37. http://dx.doi.org/10.1016/j.forpol.2011.09.004

Brown, H. C. P., J. N. Nkem, D. J. Sonwa, and Y. Bele. 2010. Institutional adaptive capacity and climate change response in the Congo Basin forests of Cameroon. Mitigation and Adaptation Strategies for Global Change 15(3):263-282. http://dx.doi. org/10.1007/s11027-010-9216-3

Bulkeley, H., and P. Newell. 2010. Governing climate change. Routledge, London, UK.

Bumpus, A., and D. Liverman. 2011. Carbon colonialism? Offsets, greenhouse gas reductions, and sustainable development. Pages 203-224 in R. Peet, P. Robbins, and M. Watts, editors. Global political ecology. Routledge, London, UK.

Bushley, B. R. 2014. REDD+ policy making in Nepal: toward state-centric, polycentric, or market-oriented governance? Ecology and Society 19(3): 34. http://dx.doi.org/10.5751/ ES-06853-190334

Casson, A., and K. Obidzinski. 2002. From new order to regional autonomy: shifting dynamics of "illegal" logging in Kalimantan, Indonesia. World Development 30(12):2133-2151. http://dx.doi. org/10.1016/S0305-750X(02)00125-0

Corbera, E., and H. Schroeder. 2011. Governing and implementing REDD+. Environmental Science \& Policy 14 (2):89-99. http://dx.doi.org/10.1016/j.envsci.2010.11.002

Di Gregorio, M., M. Brockhaus, T. Cronin, and E. Muharrom. 2012. Politics and power in national REDD+ policy processes. Pages 69-90 in A. Angelsen, M. Brockhaus, W. D. Sunderlin, and L. V. Verchot, editors. Analysing REDD+: challenges and choices. Center for International Forestry Research, Bogor, Indonesia.

Di Gregorio, M., M. Brockhaus, T. Cronin, E. Muharrom, L. Santoso, S. Mardiah, and M. Büdenbender. 2013. Equity and REDD+ in the media: a comparative analysis of policy discourses. Ecology and Society 18(2): 39. http://dx.doi. org/10.5751/ES-05694-180239

Dkamela, G. P. 2010. The context of REDD+ in Cameroon: drivers, agents, and institutions. Occasional Paper No. 57. Center for International Forestry Research, Bogor, Indonesia.

Dkamela, G., M. Brockhaus, F. Kengoum Djiegni, J. Schure, and S. Assembe Mvondo. 2014. Lessons for REDD+ from Cameroon's past forestry law reform: a political economy analysis. Ecology and Society 19(3): 30. http://dx.doi.org/10.5751/ ES-06839-190330

Doherty, E., and H. Schroeder. 2011. Forest tenure and multilevel governance in avoiding deforestation under REDD+. Global Environmental Politics 11(4):66-88. http://dx.doi.org/10.1162/ GLEP a 00084

Driscoll, R., Z. Kizilbash Agha, M. Cali, and D. W. te Velde. 2007. Growth and trade in Africa's second generation poverty reduction strategies. Overseas Development Institute, London, UK.
Environmental Investigation Agency. 2011. Crossroads: the illicit timber trade between Laos and Vietnam. Environmental Investigation Agency, London, UK.

Ernstson, H., S. Barthel, E. Andersson, and S. T. Borgström. 2010. Scale-crossing brokers and network governance of urban ecosystem services: the case of Stockholm. Ecology and Society 15(4): 28. [online] URL: http://www.ecologyandsociety.org/ vol15/iss4/art28/

Evers, A. 1990. Shifts in the welfare mix: introducing a new approach to the study of transformations in welfare and social policy. Pages 7-30 in A. Evers and H. Winterberg, editors. Shifts in the welfare mix: their impact on work, social services and welfare policies. Campus Verlag, Frankfurt, Germany.

Fischer M., A. Fischer, and P. Sciarini. 2009. Power and conflict in the Swiss political elite: an aggregation of existing network analyses. Swiss Political Science Review 15(1):31-62. http://dx.doi. org/10.1002/j.1662-6370.2009.tb00122.x

Forest Carbon Partnership Facility (FCPF). 2013. REDD readiness progress fact sheet: Indonesia. FCPF, Washington, D. C., USA.

Forsyth, T. 2009. Multilevel, multiactor governance in REDD+: participation, integration and coordination. Page 113-122 in A. Angelsen, M. Brockhaus, M. Kanninen, E. Sills, W. D. Sunderlin, and S. Wertz-Kanounnikoff. Realising REDD+: national strategy and policy options. Center for International Forestry Research, Bogor, Indonesia.

Freeman, L. C. 1978-1979. Centrality in social networks conceptual clarification. Social Networks 1(3):215-239. http://dx. doi.org/10.1016/0378-8733(78)90021-7

Gallemore, C. T., R. Dini Prasti H., and M. Moeliono. 2014. Discursive barriers and cross-scale forest governance in Central Kalimantan, Indonesia. Ecology and Society 19(2): 18. http://dx. doi.org/10.5751/ES-06418-190218

Gebara, M., L. Fatorelli, P. May, and S. Zhang. 2014. REDD+ policy networks in Brazil: constraints and opportunities for successful policy making. Ecology and Society 19(3): 53. http:// dx.doi.org/10.5751/ES-06744-190353

Giddens, A. 1984. The constitution of society: outline of the theory of structuration. Polity, Cambridge, UK.

Giddens, A. 2009. The politics of climate change. Polity, Cambridge, UK.

Government of Papua New Guinea (GovPNG). 1975. Constitution of the independent state of Papua New Guinea. GovPNG, Port Moresby, Papua New Guinea.

Griffiths, T. 2009. Seeing "REDD": forests, climate change mitigation and the rights of indigenous peoples and local communities. Forest Peoples Programme, Moreton-in-Marsh, UK.

Grindle, M. S. 1996. Challenging the state: crisis and innovation in Latin America and Africa. Cambridge University Press, Cambridge, UK. http://dx.doi.org/10.1017/CBO9780511521829 
Guardian. 2011. Papua New Guinea in crisis as two claim to be prime minister. 14 December. [online] URL: http://www. guardian.co.uk/world/2011/dec/14/papua-new-guinea-prime-ministership

Heaney, M. T. 2014. Multiplex networks and interest group influence reputation: an exponential random graph model. Social Networks 36:66-81. http://dx.doi.org/10.1016/j.socnet.2012.11.003

Indrarto, G. B., P. Murharjanti, J. Khatarina, I. Pulungan, F. Ivalerina, J. Rahman, M. N. Prana, I. A. P. Resosudarmo, and E. Muharrom. 2012. The context of REDD+ in Indonesia: drivers, agents and institutions. Working Paper No. 92. Center for International Forestry Research, Bogor, Indonesia.

Kanninen, M., D. Murdiyarso, F. Seymour, A. Angelsen, S. Wunder, and L. German, editors. 2007. Do trees grow on money? The implications of deforestation research for policies to promote $R E D D$. Center for International Forestry Research, Bogor, Indonesia.

Katzenstein, M. F. 1998. Stepsisters: feminist movement activism in different institutional spaces. Pages 195-216 in D. S. Meyer and S. Tarrow, editors. The social movement society: contentious politics for a new century. Rowman and Littlefield, Lanham, Maryland, USA.

Kengoum, D. F. 2011. REDD+ politics in the media: a case study from Cameroon. Working Paper No. 51. Center for International Forestry Research, Bogor, Indonesia.

Kenis, P., and V. Schneider. 1991. Policy networks and policy analysis: scrutinizing a new analytical toolbox. Pages 25-59 in B. Marin and R. Mayntz, editors. Policynetworks: empirical evidence and theoretical considerations. Westview, Boulder, Colorado, USA.

Knoke, D., F. U. Pappi, J. Broadbent, and Y. Tsujinaka. 1996. Comparing policy networks: labor politics in the U.S., Germany, and Japan. Cambridge University Press, Cambridge, UK. http:// dx.doi.org/10.1017/CBO9781139174497

Korhonen-Kurki, K., J. Sehring, M. Brockhaus, and M. Di Gregorio. 2014. Enabling factors for establishing REDD+ in a context of weak governance: a qualitative comparative analysis. Climate Policy 14(2):167-186. http://dx.doi.org/10.1080/146930$\underline{62.2014 .852022}$

Kriesi, H., S. Adam, and M. Jochum. 2006. Comparative analysis of policy networks in Western Europe. Journal of European Public Policy 13(3):341-361. http://dx.doi.org/10.1080/13501760500528803

Kriesi, H., and M. Jegen. 2001. The Swiss energy policy elite: the actor constellation of a policy domain in transition. European Journal of Political Research 39(2):251-287. http://dx.doi. org/10.1111/1475-6765.00577

Labianca, G., and D. J. Brass. 2006. Exploring the social ledger: negative relationships and negative asymmetry in social networks in organizations. Academy of Management Review 31(3):596-614. http://dx.doi.org/10.5465/AMR.2006.21318920

Larson, A. M., M. Brockhaus, W. D. Sunderlin, A. Duchelle, A. Babon, T. Dokken, T. T. Pham, I. A. P. Resosudarmo, G. Selaya, A. Awono, and T.-B. Huynh. 2013. Land tenure and REDD+: the good, the bad and the ugly. Global Environmental Change 23 (3):678-689. http://dx.doi.org/10.1016/j.gloenvcha.2013.02.014
Latour, B. 1986. The powers of association. Pages 264-280 in J. Law, editor. Power, action, belief: a new sociology of knowledge? Routledge and Kegan Paul, London, UK.

Lederer, M. 2011. From CDM to REDD+-what do we know for setting up effective and legitimate carbon governance? Ecological Economics 70(11):1900-1907. http://dx.doi.org/10.1016/ j.ecolecon.2011.02.003

Luttrell, C. 2007. Ownership in relation to the design of verification systems. VERIFOR Briefing Paper. Overseas Development Institute, London, UK.

Luttrell, C., L. Loft, M. F. Gebara, D. Kweka, M. Brockhaus, A. Angelsen, and W. D. Sunderlin. 2013. Who should benefit from REDD+? Rationales and realities. Ecology and Society 18(4): 52. http://dx.doi.org/10.5751/ES-05834-180452

Luttrell, C., I. A. P. Resosudarmo, E. Muharrom, M. Brockhaus, and F. Seymour. 2014. The political context of REDD + in Indonesia: constituencies for change. Environmental Science \& Policy 35:67-75. http://dx.doi.org/10.1016/j.envsci.2012.10.001

Marsh, D., and R. W. A. Rhodes. 1992. Policy networks in British government. Clarendon Press, Oxford, UK. http://dx.doi. org/10.1093/acprof:oso/9780198278528.001.0001

May, P. H., B. Calixto, and M. F. Gebara. 2011a. REDD+ politics in the media: a case study from Brazil. Working Paper No. 55. Center for International Forestry Research, Bogor, Indonesia.

May, P. H., B. Millikan, and M. F. Gebara. 2011b. The context of REDD+ in Brazil: drivers, agents, and institutions. Occasional Paper No. 55. Center for International Forestry Research, Bogor, Indonesia.

Meridian Institute. 2009. Reducing emissions from deforestation and forest degradation: an options assessment report. Report prepared for the Government of Norway by A. Angelsen, S. Brown, C. Loisel, L. Peskett, C. Streck, and D. Zarin. Meridian Institute, Washington, D.C., USA. [online] URL: http://merid. org/content/projects/Government $\% 20$ of $\% 20$ Norway $\% 20$ REDD $\%$ 200ptions $\% 20$ Assessment $\% 20$ Report.aspx

Moeliono, M., C. Gallemore, L. Santoso, M. Brockhaus, and M. Di Gregorio. 2014. Information networks and power: confronting the "wicked problem" of REDD+ policy in Indonesia. Ecology and Society 19(2): 9. http://dx.doi.org/10.5751/ES-06300-190209

Moeliono, M., L. Santoso, and C. Gallemore. 2013. REDD+ policy networks in Indonesia. CIFOR Infobrief No. 63. Center for International Forestry Research, Bogor, Indonesia.

Murdiyarso, D., S. Dewi, D. Lawrence, and F. Seymour. 2011. Indonesia's forest moratorium: a stepping stone to better forest governance? Working Paper No. 76. Center for International Forestry Research, Bogor, Indonesia.

Murdoch, J., and T. Marsden. 1995. The spatialization of politics: local and national actor-spaces in environmental conflict. Transactions of the Institute of British Geographers 20(3):368-380. http://dx.doi.org/10.2307/622657

Newell, P. 2000. Climate for change: non-state actors and the global politics of the greenhouse. Cambridge University Press, Cambridge, UK. http://dx.doi.org/10.1017/CBO9780511529436 
Newig, J., D. Günther, and C. Pahl-Wostl. 2010. Synapses in the network: learning in governance networks in the context of environmental management. Ecology and Society 15(4): 24. [online] URL: http://www.ecologyandsociety.org/vol15/iss4/ $\underline{\operatorname{art} 24 /}$

Okerere, C., and K. Dooley. 2010. Principles of justice in proposals and policy approaches to avoided deforestation: towards a post-Kyoto climate agreement. Global Environmental Change 20(1):82-95. http://dx.doi.org/10.1016/j.gloenvcha.2009.08.004

Paudel, N. S., D. B. Khatri, D. R. Khanal, and R. Karki. 2011. The context of REDD+ in Nepal: drivers, agents, and institutions. Occasional Paper No. 81. Center for International Forestry Research, Bogor, Indonesia.

Peskett, L., and M. Brockhaus. 2009. When REDD+ goes national: a review of realities, opportunities and challenges. Pages 25-43 in A. Angelsen, M. Brockhaus, M. Kanninen, E. Sills, W. D. Sunderlin, and S. Wertz-Kanounnikoff, editors. Realising REDD+: national strategy and policy options. Center for International Forestry Research, Bogor, Indonesia.

Pham, T. T. 2011. REDD+ politics in the media: a case study from Vietnam. Working Paper No. 53. Center for International Forestry Research, Bogor, Indonesia.

Pham, T. T., M. Brockhaus, G. Wong, N. D. Le, J. S. Tjajadi, L. Loft, C. Luttrell, and S. Assembe-Mvondo. 2013. Approaches to benefit sharing: a preliminary comparative analysis of 13 REDD+ countries. Working Paper No. 108. Center for International Forestry Research, Bogor, Indonesia.

Pham, T. T., M. Di Gregorio, R. Carmenta, M. Brockhaus, and D. N. Le. 2014. The REDD+ policy arena in Vietnam: participation of policy actors. Ecology and Society 19(2): 22. http://dx.doi.org/10.5751/ES-06389-190222

Pham, T. T., M. Moeliono, T. H. Nguyen, H. T. Nguyen, and T. $\mathrm{H}$. Vu. 2011. The context of REDD+ in Vietnam: drivers, agents and institutions. Occasional Paper No. 75. Center for International Forestry Research, Bogor, Indonesia.

Phelps, J., E. L. Webb, and A. Agrawal. 2010. Does REDD+ threaten to recentralize forest governance? Science 328 (5976):312-313. http://dx.doi.org/10.1126/science.1187774

Poteete, A. 2012. Levels, scales, linkages, and other "multiples" affecting natural resources. International Journal of the Commons 6(2):134-150.

Rantala, S., and M. Di Gregorio. 2014. Multistakeholder governance in action: REDD+ discourse coalitions in Tanzania. Ecology and Society 19(2): 66. http://dx.doi.org/10.5751/ ES-06536-190266

Ridwan, M. F. 2013. Mubariq: menanti lembaga REDD. Jurnal Nasional. 20 February. [online] URL: http://www.jurnas.com/ news/83353/Mubariq-Menanti-Lembaga-REDD-2013/1/Sosial-Budaya/ Lingkungan

Romijn, E., M. Herold, L. Kooistra, D. Murdiyarso, and L. V. Verchot. 2012. Assessing capacities of non-Annex I countries for national forest monitoring in the context of REDD+. Environmental Science \& Policy 19-20:33-48. http://dx.doi. org/10.1016/j.envsci.2012.01.005
Sabatier, P. A., and H. C. Jenkins-Smith, editors. 1993. Policy change and learning: an advocacy coalition approach. Westview, Boulder, Colorado, USA.

Scott, J. 2000. Social network analysis: a handbook. Second edition. Sage, London, UK.

Sehring, J., K. Korhonen-Kurki, and M. Brockhaus. 2013. Qualitative comparative analysis (QCA): an application to compare national REDD+ policy processes. Working Paper 121. Center for International Forestry Research, Bogor, Indonesia.

Seymour, F., and A. Angelsen. 2012. Summary and conclusions: REDD+ without regrets. Pages 317-334 in A. Angelsen, M. Brockhaus, W. D. Sunderlin, and L. V. Verchot, editors. Analysing $R E D D+$ : challenges and choices. Center for International Forestry Research, Bogor, Indonesia.

Sikor, T., and P. X. To. 2011. Illegal logging in Vietnam: Lam Tac (forest hijackers) in practice and talk. Society \& Natural Resources: An International Journal 24(7):688-701. http://dx.doi. org/10.1080/08941920903573057

Somorin, O. A., H. C. P. Brown, I. J. Visseren-Hamakers, D. J. Sonwa, B. Arts, and J. Nkem. 2012. The Congo Basin forests in a changing climate: policy discourses on adaptation and mitigation (REDD+). Global Environmental Change 22 (1):288-298. http://dx.doi.org/10.1016/j.gloenvcha.2011.08.001

Stickler, C. M., D. C. Nepstad, A. A. Azevedo, and D. G. McGrath. 2013. Defending public interests in private lands: compliance, costs and potential environmental consequences of the Brazilian Forest Code in Mato Grosso. Philosophical Transactions of the Royal Society B Biological Sciences 368 (1619):20120160. http://dx.doi.org/10.1098/rstb.2012.0160

Van Waarden, F. 1992. Dimensions and types of policy networks. European Journal of Political Research 21:29-52. http://dx.doi. org/10.1111/j.1475-6765.1992.tb00287.x

Wasserman, S., and K. Faust. 1994. Social network analysis: methods and applications. Cambridge University Press, Cambridge, UK. http://dx.doi.org/10.1017/CBO9780511815478

Wertz-Kanounnikoff, S., and D. McNeill. 2012. Performance indicators and REDD+ implementation. Pages 233-246 in A. Angelsen, M. Brockhaus, W. D. Sunderlin, and L. V. Verchot, editors. Analysing REDD+: challenges and choices. Center for International Forestry Research, Bogor, Indonesia.

Westholm, L. 2010. Getting ready for REDD+. Focali Report, 2010:01. University of Gothenburg, Gothenburg, Sweden.

White, H. 1961. Management conflict and sociometric structure. American Journal of Sociology 67(2):185-199. http://dx.doi. org/10.1086/223084

World Bank. 2006. Strengthening forest law enforcement and governance: addressing a systemic constraint to sustainable development. The World Bank, Washington, D.C., USA. 


\section{Appendix 1:}

Table A1. Response rates of the social organization survey

\begin{tabular}{|c|c|c|c|c|c|c|c|}
\hline & Indonesia & Brazil & Nepal & Vietnam & Tanzania & Cameroon & PNG \\
\hline Domain actors & 115 & 64 & 53 & 52 & 58 & 64 & 66 \\
\hline Surveyed & 64 & 56 & 34 & 52 & 53 & 42 & 45 \\
\hline Response rate & $56 \%$ & $88 \%$ & $64 \%$ & $100 \%$ & $91 \%$ & $66 \%$ & $68 \%$ \\
\hline $\begin{array}{l}\text { Average } \\
\text { reputational power } \\
\text { of ALL actors* }\end{array}$ & 8.96 & 15.17 & 13.22 & 11.08 & 18.91 & 13.4 & 15.18 \\
\hline $\begin{array}{l}\text { Avg indegree of } \\
\text { surveyed actors }\end{array}$ & 12.38 & 15.91 & 14.79 & 11.08 & 19.38 & 13.95 & 15.96 \\
\hline $\begin{array}{l}\text { Avg indegree of not } \\
\text { surveyed actors }\end{array}$ & 4.67 & 10 & 11.08 & - & 14 & 12.36 & 13.53 \\
\hline $\begin{array}{l}\text { Not surveyed with } \\
\text { indegree > avg } \\
\text { indegree }\end{array}$ & 6 & 1 & 5 & - & 2 & 6 & 6 \\
\hline $\begin{array}{l}\text { Most influential } \\
\text { among actors not } \\
\text { surveyed }\end{array}$ & 10th & 14 th & 6th & - & 10th & $1 \mathrm{st}$ & 4th \\
\hline
\end{tabular}

